\title{
PROTECTIVE EFFECTS OF SYSTEMIC PIRACETAM TREATMENT ON TESTICULAR TORSION/DETORSION DAMAGE IN RATS: A DOSE-RESPONSE STUDY
}

\author{
Ratlarda Sistemik Pirasetam Tedavisinin Testis Torsiyon/Detorsiyon Hasarında Koruyucu
}

Etkileri: Doz Bă̆ımlı Çalışma

\author{
Devrim TUĞLU ${ }^{1}$, Ercan YUVANC ${ }^{1}$, Fatih BAL ${ }^{1}$, Erdal YILMAZ ${ }^{1}$, Pınar ATASOY ${ }^{2}$, \\ Üçler KISA ${ }^{3}$, Ertan BATÍSLAM ${ }^{1}$
}

\author{
${ }^{1}$ Klrlkkale University Faculty of Medicine, Department of Urology, KIRIKKALE \\ ${ }^{2}$ Kirlkkale University, Faculty of Medicine, Department of Pathology, KIRIKKALE \\ ${ }^{3}$ Kırlkkale University, Faculty of Medicine, Department of Medical Biochemistry, KIRIKKALE
}

\begin{abstract}
ÖZ

Objective: The aim of the present study was to determine the preventive effects of piracetam on testes against to oxidative damage which induced by ischemia/reperfusion.

Material and Methods: The rats randomly divided to 4 groups. Group 1 was considered as control/sham, Group 2 was I/R (Ischemia/Reperfusion), Group 3 was piracetam ( $250 \mathrm{mg} / \mathrm{kg}$; i.p.) $+\mathrm{I} / \mathrm{R}$ and Group 4 was piracetam $(500 \mathrm{mg} / \mathrm{kg}$; i.p. $)+\mathrm{I} / \mathrm{R}$. Piracetam was given intraperitoneally (i.p) after $60 \mathrm{mins}$ of testicular torsion. In all 4 groups, the ipsilateral (left testis) and contralateral testes (right testis) of rats were excised 6 hours after beginning of the procedure.

Results: Piracetam administration significantly increased total antioxidant capacity and decreased oxidative stress index. There was no statistically difference according to Johnsen's scoring system among the groups in the ipsilateral or contralateral testes.

Conclusion: Piracetam administration decreased oxidative damage which induced by ischemia/reperfusion in testes via increasing antioxidant activity and decreasing oxidative stres scores. However, the treatment was not induced alteration in histopathological examination and spermatogenesis scores.

Amaç: Çalışmamızda amacımız, testiste iskemi/reperfüsyon (I/R) etkisi ile oluşan oksidatif hasar üzerine pirasetamın koruyucu etkilerini araştırmaktır.

Gereç ve Yöntemler: Ratlar rastgele 4 gruba ayrıldı. Grup 1= sham (kontrol), Grup 2=I/R (iskemi/reperfüsyon), Grup $3=\mathrm{I} / \mathrm{R}+$ pirasetam $(250 \mathrm{mg} / \mathrm{kg}$; i.p. $)$ ve Grup $4=\mathrm{I} / \mathrm{R}+$ pirasetam $(500 \mathrm{mg} / \mathrm{kg}$; i.p.). Pirasetam intraperitoneal yolla testis torsiyonunu takiben 60. dakikada verilmiștir. Her 4 grupta işlemin başlangıcından 6 saat sonra ipsilateral sol testis ve kontralateral sağ testisler çıkarılmıştır.

Bulgular: Pirasetam uygulaması total antioksidan kapasiteyi istatistiksel olarak anlamlı biçimde arttırırken, oksidatif stres indeks oranını da istatistiksel olarak anlamlı biçimde azaltımıştır. İpsilateral ve kontralateral testis grupları arasında Johnsen skorlama sistemine göre istatistiksel farklılık saptanmamıştır.

Sonuç: Pirasetam uygulaması, testislerde iskemi reperfüzyon ile oluşan oksidatif hasarı antioksidan kapasiteyi arttırarak ve oksidatif stres skorlarını düşürerek azaltmıştır; ancak, histopatolojik incelemede ve spermatogenes skorlarında bir değişime neden olmamıştır.
\end{abstract}




\section{INTRODUCTION}

Torsion of testes is a serious urologic surgical emergencies that leads to ischemia of testes therefore surgery is generally needed to restore blood circulation (1). The ischemic damage due to testicular torsion and the reperfusion injury after detorsion causes a number of structural and biochemical changes in the tissue that lead to the emergent status which need to be managed urgently. Torsion is the cause for an ischemic injury in the testicular parenchym whereas detorsion is leading to reperfusion and is associated with cellular damage by causing biochemical and structural changes in the testicular tissue. Studies have shown that oxygen free radicals are responsible in the ischemia-reperfusion injury and may cause harmful effects by disrupting the structural elements of the tissue. Determination of applicable antioxidant agents in order to use with the operation to protect the testicles from I/R damage, is a practically meaningful objective (2). It has been declared that piracetam may have cytoprotective, antihypoxic, antioxidant properties and may reduce the consumption of oxygen in the mitochondria by inhibiting lipid peroxidation of free radicals (3-5).

Piracetam is a nootropic agent used in neurological sciences because of its rheological, anti-thrombotic, and neuro-protective properties (6). After proving of its influence on improving micro-circulation, the area of usage for this drug extended (7).

The purpose of the present study was to investigate the anti-oxidant properties of systemic piracetam administration on ipsilateral/contrlateral testes after ischemia in a rat design of testicular torsion and detorsion (T/D).

\section{MATERIALS AND METHODS}

The mentioned design accepted by Ankara Training and Research Hospital local ethics commitee (Protocol Number: 314/2014). Wistar albino male rats weighing range 250-300 $\mathrm{g}$ and 6-month-old were used in the study. Rats were anaesthetised by injection of a mixture $(1 / 4: \mathrm{v} / \mathrm{v})$ of xylazine $(10 \mathrm{mg} / \mathrm{kg})+$ ketamine $(90 \mathrm{mg} / \mathrm{kg})$ intramuscularly for general anesthesia.

\section{Experimental groups}

The rats randomly divided to 4 groups:

For Group 1 (sham, control) $(n=8)$, the left testicles of the rats were reached by scrotal cut and dissection. After dissection the incisions were closed with $5 / 0$ silk sutures without implementation any process.

For Group $2(I / R)(n=8)$, the left testicles of the rats were reached by scrotal cut and dissection. The left testis of each rat was torsed $720^{\circ}$ counter-clockwise and sutured to scrotum wall with 5/0 silk. The incisions were sutured with $5 / 0$ silk where the left testicles remain torsed. The testis was detorsed after 4 hours of torsion. The scrotum was again sutured with $5 / 0$ silk. Not any treatment was administered.

For Group 3 (I/R + Piracetam $250 \mathrm{mg} / \mathrm{kg}) \quad(\mathrm{n}=8)$, additionally to the design performed in group 2, 250 $\mathrm{mg} / \mathrm{kg}$ of Piracetam was applied intraperitoneally (i.p) to each rat $30 \mathrm{~min}$. before detorsion.

For Group 4 (I/R+ Piracetam $500 \mathrm{mg} / \mathrm{kg}) \quad(\mathrm{n}=8)$, additionally to the design performed in group 2, 500 $\mathrm{mg} / \mathrm{kg}$ of Piracetam was applied i.p. to each rat $30 \mathrm{~min}$. before detorsion.

In all 4 groups, six hours after beginning of the design, the ipsilateral (Left testis) (L) and contralateral testes (Right testis) (R) of rats were extracted for histologic investigation and biochemical evaluations.

\section{Histopathologic Investigation}

Initially, testis tissues were placed into a fixative and embedded in paraffin, routinely and cut into sections with a microtome and stained with haematoxylin and eosin. All testicular histology was evaluated under a light microscope with camera attachment (Olympus DP 71; Olympus, Tokyo, Japan). Histological patterns in 
seminiferous tubuli were graded using the Johnsen's score. This score details the conservation of spermatogenesis, on a scale from 1 to 10 , with respect to the lack or being of the primary cell types staged in order of maturity. A Johnsen's score of 9 or 10 remarks regular histology, a score of 8 indicates hypospermatogenesis, a score of 3-7 mentions maturation interception, a score of 2 implies germinal cell aplasia, and a score of 1 demonstrates tubular fibrosis (8) (Table 1). The germinal epithelia of at least 50 tubules was evaluated for each testis, and score was determined using Johnsen's mean testicular biopsy score (MTBS) criteria (8). Histologic evaluations were performed by an experienced pathologist.

\section{Biochemical Evaluation}

Frozen testis samples which were stored frozen at -80 ${ }^{0} \mathrm{C}$, were used fort he analysis.

\section{Assessment of Total Antioxidant Capacity (TAC):}

TAC level was calculated in mmol Trolox equivalent/L using an automated measurement method (9).

Assessment of Total Oxidant Status (TOS): TOS level was calculated in $\mu \mathrm{mol} \mathrm{H} 2 \mathrm{O} 2$ equivalent/L using an automated measurement method (10).

Computation of Oxidative stress index (OSI): OSI value was indicated the TOS/TAC ratio value. To calculate, the unit of TAC, mmol Trolox equivalent/L, was transformed to $\mu \mathrm{mol}$ Trolox equivalent/L, and OSI was measured as: OSI $=[(\mathrm{TOS}, \mu \mathrm{mol} \mathrm{H} 2 \mathrm{O} 2$ equivalent/L) / (TAC, $\mu$ mol Trolox equivalent/L) $\times$ 100] (10).

\section{Statistical Analysis}

All statistical examination was carried out using SPSS version 15.0 (SPSS; Chicago, IL, USA). All normally data were presented as mean \pm standard deviation (SD) and non-normally separated info were defined as median (25-75\%). Student $t$ and One way ANOVA test with Bonferroni adjustment were used for comparing normally distributed data. Diversities in measured factors between groups were resolved with a nonparametric test (Kruskal-Wallis). Dual comparisons among the groups displaying considerable values were measured with a Mann-Whitney $U$ test. Subsequently, the relation between these parameters was evaluated using linear regression analysis (Backward). These distinctions were accepted significant when possibility was less than 0,05 .

\section{RESULTS}

\section{Biochemical Results}

The tissue TAC levels 4 in both torsioned and detorsioned testicles of Group 3 and Group 4 were statistically $(P<0.001)$ higher than those of Group 2 (I / R) (Table 2-3). The tissue TOS levels in both torsioned and detorsioned testicles of Group 3 and Group 4 were not significantly different than those in Group 2. The tissue OSI levels in both the torsioned and contralateral testicles of Group 3 and Group 4 were statistically lower than in Group $2(P<0.001)$ (Tables 2 and 3).

\section{Histological Results}

Histopathological changes were not observed in Group 1 (Figure 1). Johnsen's testicular biopsy scor in both torsioned and contralateral testicles of Group 2, histopathologically demonstrated deterioration, desquamation, disarrangement in germinal cell, interstitial edema, capillary blockage and hemorrhage and in Groups 3 and 4. These histopathological changes were similar compared to Group 2 (Figure $2,3,4)$. There is no statistically change observed in Johnsen's scoring system among Groups 2, 3 and 4 (Table 4). 


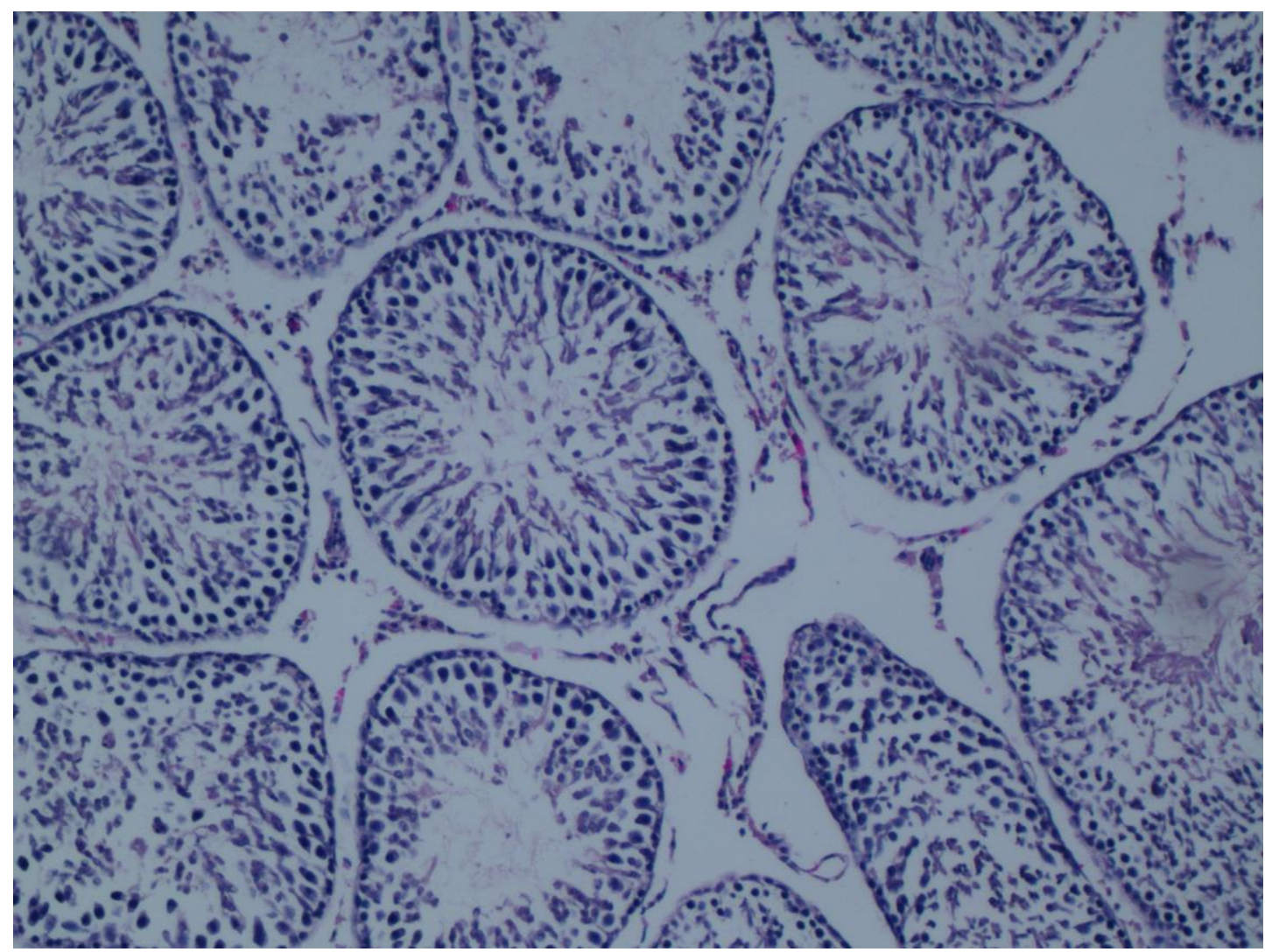

Figure 1. Group 1. Define normal seminiferous tubules. H\&E, reduced from x100. Photomicrograph show left testes.

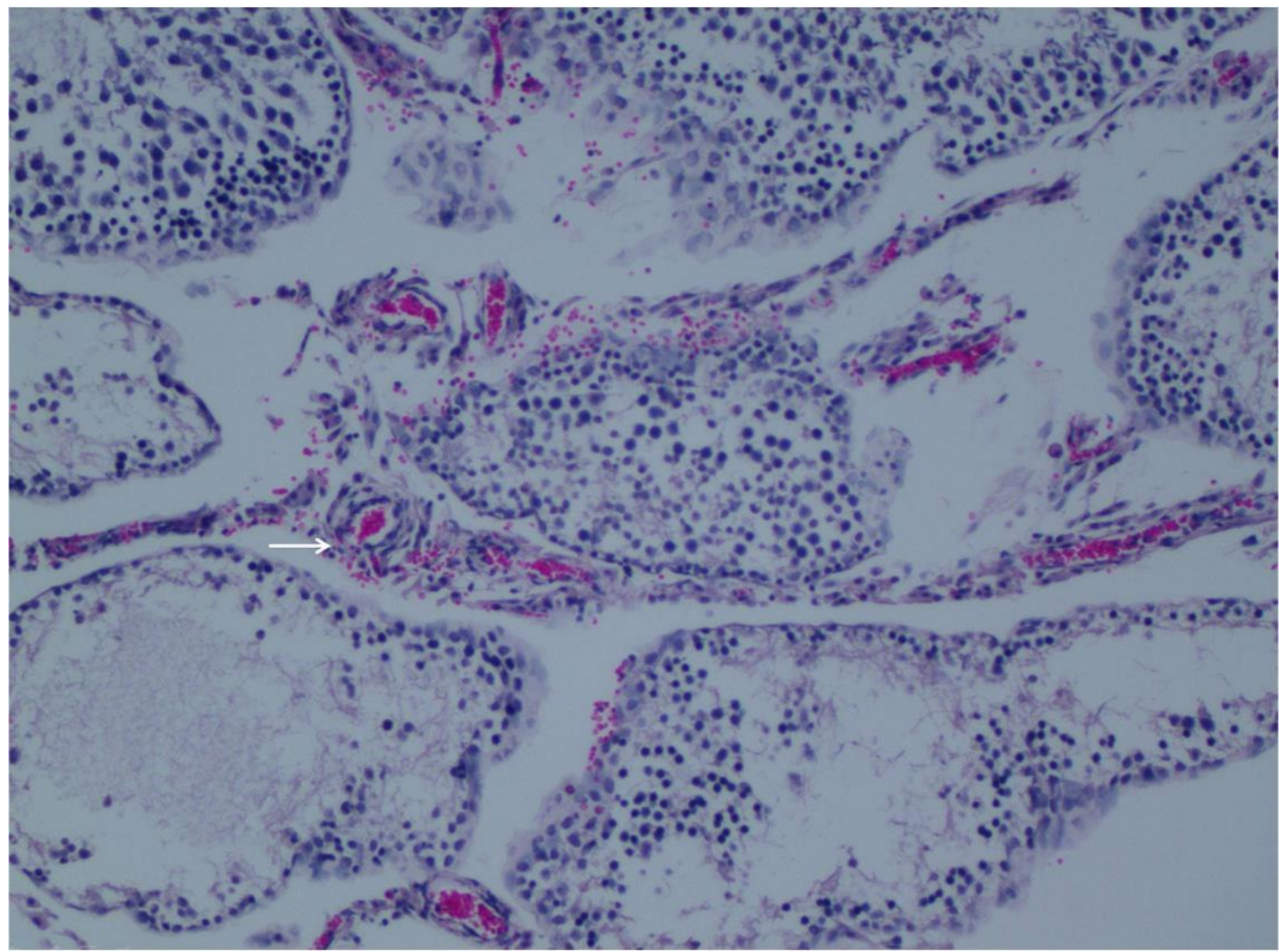

Figure 2. Group 2. Define interstitial edema, hemorrhage(arrow) and less distinct seminiferous tubule borders. H\&E x100). Photomicrograph show left testes. 


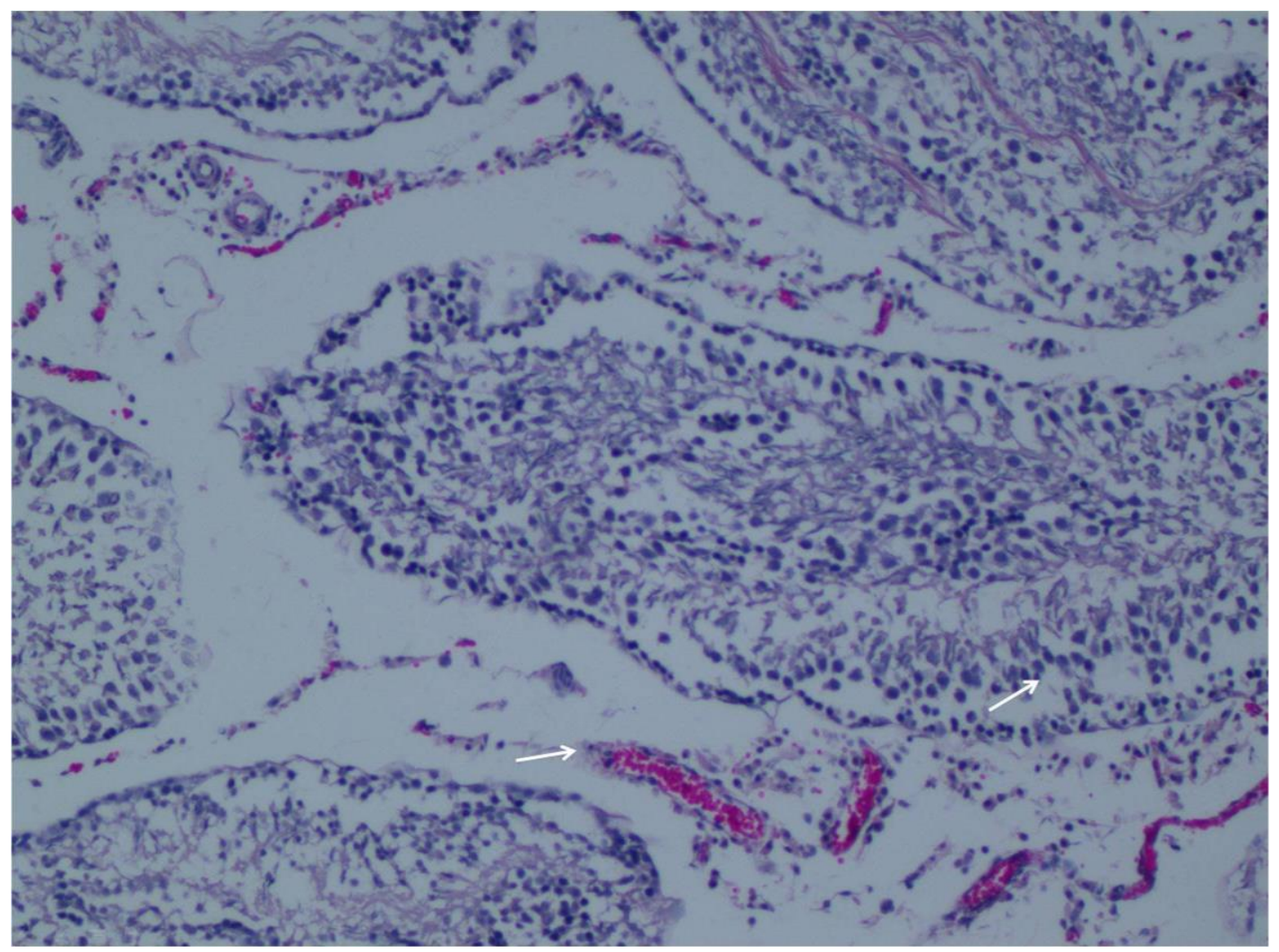

Figure 3. Piracetam $250 \mathrm{mg} / \mathrm{kg}$ group 3. Define reduced edema, hemorrhage(arrow) and well organized germ cells(arrow). (H\&E x100). Photomicrograph show left testes.

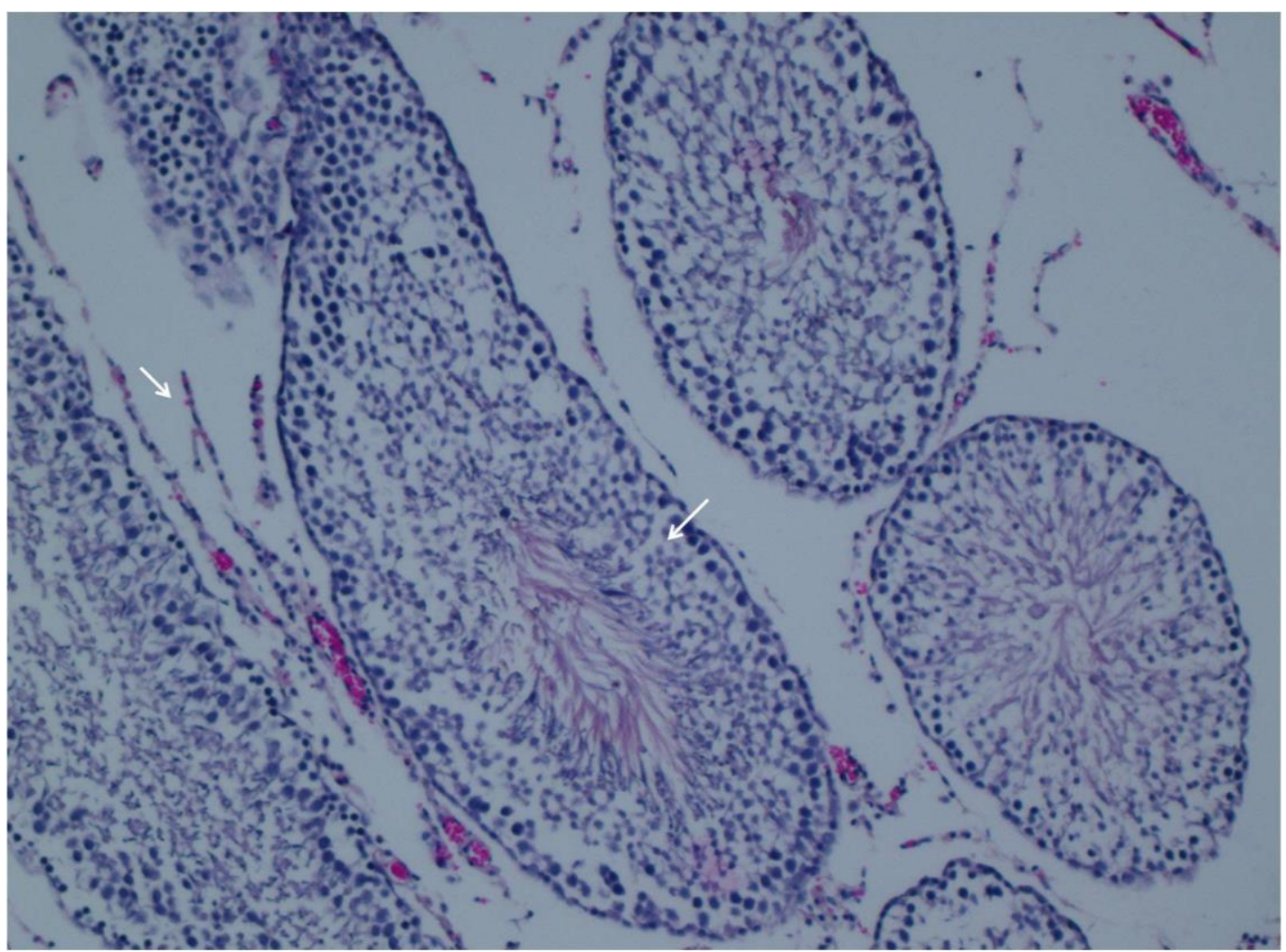

Figure 4. Piracetam $500 \mathrm{mg} / \mathrm{kg}$ group 4. Define reduced edema, hemorrhage(arrow) and well organized germ cells(arrow). (H\&E x100). Photomicrograph show left testes. 
Table 1: Modified Johnsen score system

\begin{tabular}{cl} 
Johnsen score & Description \\
\hline 10 & Full spermatogenesis \\
9 & Slightly impaired spermatogenesis, many late spermatids, disorganized epithelium \\
8 & Less than five spermatozoa per tubule, few late spermatids \\
7 & No spermatozoa, no late spermatids, many early spermatids \\
6 & No spermatozoa, no late spermatids, few early spermatids \\
5 & No spermatozoa or spermatids, many spermatocytes \\
4 & No spermatozoa or spermatids, few spermatocytes \\
3 & Spermatogonia only \\
2 & No germinal cells, Sertoli cells only \\
1 & No seminiferous epithelium \\
\hline
\end{tabular}

Table 2: Torsion group; Kruskal Wallis Test, Median (25-75\%), $P<0.001$

\begin{tabular}{|c|c|c|c|c|c|}
\hline & $\begin{array}{l}\text { Group } 1 \\
(\mathrm{n}=8)\end{array}$ & $\begin{array}{l}\text { Group } 2 \\
(\mathrm{n}=8)\end{array}$ & $\begin{array}{c}\text { Group } 3 \\
(n=8)\end{array}$ & $\begin{array}{c}\text { Group } 4 \\
(n=8)\end{array}$ & $\begin{array}{c}P \\
\text { (Kruskal Wallis) }\end{array}$ \\
\hline $\begin{array}{l}\text { TAC } \\
\text { (nmol Trolox Equiv. } \\
\text { per mg protein) }\end{array}$ & $\begin{array}{c}1.80 \\
(0.82-4.74)\end{array}$ & $\begin{array}{c}1.01 \\
(0.27-2.19)\end{array}$ & $\begin{array}{c}8.54 \\
(6.52-1.49)\end{array}$ & $\begin{array}{c}9.8 \\
(8.7-10.6)\end{array}$ & $<0.001$ \\
\hline $\begin{array}{l}\text { TOS } \\
\text { (nmol H2O2 Equiv. } \\
\text { per mg protein) }\end{array}$ & $\begin{array}{c}1.64 \\
(0.48-2.77)\end{array}$ & $\begin{array}{c}1.14 \\
(0.72-3.25)\end{array}$ & $\begin{array}{c}1.33 \\
(0.56-2.10)\end{array}$ & $\begin{array}{c}1.85 \\
(1.43-2.40)\end{array}$ & NS \\
\hline $\begin{array}{l}\text { OSI } \\
\text { (arbitrary unit) }\end{array}$ & $\begin{array}{c}1.35 \\
(0.40-1.77)\end{array}$ & $\begin{array}{c}0.97 \\
(0.68-3.30)\end{array}$ & $\begin{array}{c}0.17 \\
(0.08-0.22)\end{array}$ & $\begin{array}{c}0.19 \\
(0.15-0.22)\end{array}$ & $<0.001$ \\
\hline
\end{tabular}

NS=Statistically non significant

Values are mean $\pm \mathrm{SD}$. OSI $=$ oxidative stress index; $\mathrm{TAC}=$ total antioxidant capacity; $\mathrm{TOS}=$ total oxidative status

Table 3: Detorsion Group; Kruskal Wallis Test, Median (\%25-\%75), $P<0.001$

\begin{tabular}{|c|c|c|c|c|c|}
\hline & $\begin{array}{l}\text { Group 1R } \\
\quad(\mathrm{n}=8)\end{array}$ & $\begin{array}{l}\text { Group 2R } \\
(\mathrm{n}=8)\end{array}$ & $\begin{array}{l}\text { Group 3R } \\
\quad(n=8)\end{array}$ & $\begin{array}{l}\text { Group 4R } \\
\quad(n=8)\end{array}$ & $\begin{array}{c}P \\
\text { (KruskaleWallis) }\end{array}$ \\
\hline $\begin{array}{l}\text { TAC } \\
\text { (nmol Trolox Equiv. } \\
\text { per mg protein) }\end{array}$ & $\begin{array}{c}1.80 \\
(0.82-4.74)\end{array}$ & $\begin{array}{c}1.24 \\
(0.40-2.16)\end{array}$ & $\begin{array}{c}10.53 \\
(8.34-11.56)\end{array}$ & $\begin{array}{c}11.22 \\
(10.36-12.34)\end{array}$ & $<0.001$ \\
\hline $\begin{array}{l}\text { TOS } \\
\text { (nmol H2O2 Equiv. } \\
\text { per mg protein) }\end{array}$ & $\begin{array}{c}1.64 \\
(0.48-2.77)\end{array}$ & $\begin{array}{c}1.72 \\
(1.62-2.88)\end{array}$ & $\begin{array}{c}1.52 \\
(0.74-2.25)\end{array}$ & $\begin{array}{c}2.00 \\
(1.32-3.34)\end{array}$ & NS \\
\hline $\begin{array}{l}\text { OSI } \\
\text { (arbitrary unit) }\end{array}$ & $\begin{array}{c}1.35 \\
(0.40-1.77)\end{array}$ & $\begin{array}{c}1.09 \\
(0.78-7.27)\end{array}$ & $\begin{array}{c}0.15 \\
(0.06-0.22)\end{array}$ & $\begin{array}{c}0.14 \\
(0.12-0.26)\end{array}$ & $<0.001$ \\
\hline
\end{tabular}

$\mathrm{NS}=$ Statistically non significant

Values are mean \pm SD. OSI $=$ oxidative stress index; $\mathrm{TAC}=$ total antioxidant capacity; $\mathrm{TOS}=$ total oxidative status . 
Table 4: Degrees of some histopathological lesions of testicular sections of rats in all groups

\begin{tabular}{lccccccc}
\hline Parameters & $\begin{array}{c}\text { Group 1 } \\
(\mathrm{n}=8)\end{array}$ & $\begin{array}{c}\text { Group 2 } \\
(\mathrm{n}=8)\end{array}$ & $\begin{array}{c}\text { Group 3 } \\
(\mathrm{n}=8)\end{array}$ & $\begin{array}{c}\text { Group 4 } \\
(\mathrm{n}=8)\end{array}$ & $\begin{array}{c}\text { Group 2R } \\
(\mathrm{n}=8)\end{array}$ & $\begin{array}{c}\text { Group 3R } \\
(\mathrm{n}=8)\end{array}$ & $\begin{array}{c}\text { Group 4R } \\
(\mathrm{n}=8)\end{array}$ \\
\hline $\begin{array}{l}\text { Desquamation in germinal } \\
\text { ells }\end{array}$ & $\mathrm{ND}$ & +++ & ++ & ++ & + & + & + \\
$\begin{array}{l}\text { Disorganisation in } \\
\text { germinal cells }\end{array}$ & $\mathrm{ND}$ & ++ & ++ & + & + & + & + \\
$\begin{array}{l}\text { Degeneration in germinal } \\
\text { cells }\end{array}$ & $\mathrm{ND}$ & ++ & ++ & ++ & + & + & + \\
$\begin{array}{l}\text { Haemorrhage } \\
\begin{array}{l}\text { Interstitial oedema and } \\
\text { capillary congestion }\end{array}\end{array}$ & $\mathrm{ND}$ & ++ & ++ & ++ & + & + & + \\
$\begin{array}{l}\text { Reduction in germinal cell } \\
\text { counts }\end{array}$ & $\mathrm{ND}$ & ++ & ++ & ++ & + & + & + \\
\hline [mild (+), moderate (++), severe (+++)] & & & +++ & ++ & + & + & + \\
\hline
\end{tabular}

\section{DISCUSSION}

Torsion of testes is a surgical emergencies and must be treated quickly. Protracted torsion results to testicular ischemia and elevated grades of oxidative stress in the torsioned testes related with NO and hydrogen peroxide production, elevated lipid peroxide formation, iso-prostane accretion, anti-oxidant enzyme consumption and elevated rates of mitochondria associated apoptosis in the germline (11). Even in shorter time periods of ischemia e.g. $<3$ hours can cause to an elevated grades of oxidative stress, degradation of testicular glutathione status and the consequent reduction of spermatogenesis. Therefore, we consisted a 4 hours torsion model rotating left testis 720 degree counterclockwise to create a strong testicular injury.

Notably, the grade of peroxidative injury recognized in testicular tissue enhances ensuing detorsion, demonstrating the causation of reperfusion damage (12). The widespread opinion that testicular injury induced by a temporary ischemia is consolidated with oxidative stress is supported by the quick induction of lipid peroxidation and the companion compression of endogenic antioxidant function e.g. catalase, SOD and glutathione peroxidase (13). On the other hand, the tissue damage excited by $I / R$ can be effectively mitigated by pre-therapy with exogenic antioxidants such as garlic extract, resveratrol, selenium, phenethyl ester caffeic acid and L-carnitine (13-15).

Piracetam, a nootropic drug, has been already used for neurological, neuropsychiatrical, and neurosurgerical disorders $(6,7,16-18)$. Piracetam was first used by Rosillon D et al. in an empirical reconstructive operation and was reported that systemic administration advanced the viability of the distal part of the flap (19). Similarly, Tuncer S et al. demonstrated that systemic piracetam therapy increases survival of flaps, decreases necrosis deals, and raises vascular endothelial growth factor expression (20). Horvath B et al. have shown that piracetam is a oxygen free radical (OFR) exterminator (17). In yet different report, it was demonstrated that piracetam proceeds as an antioxidant by balancing cellular walls and developing membrane renovating capability (21).

Oxidative stress, resulting in an instability among the formation of OFR and antioxidant capacity, directs to injury of biologic macro-molecules and deterioration of regular metabolism (22). Oxidative stress in the texture consigns to increased production of OFR and/or attenuation of antioxidant defensive scheme. OFR can 
assault the poly-unsaturated fatty acids in the biologic walls and cause free radical chain reactions, catalizing to the increment of lipid peroxidation (23). The procedures utilized for the definition of oxidative stress are usually of board variety. A frequently enjoyed and lightly discoverable exponent for the serum antioxidative and oxidant qualities are the TAC and TOS $(9,10)$. In our study, TAC, TOS and OSI parameters and histopathological changes were examined to evaluate the antioxidant capacity of two different doses of Piracetam in a model of testicular torsion.

In testes, MTBS is utilized to define histopathologic injury. It is attributed on the estimation of advancing degeneration of the germinal epithelium (8). When the structure of the testicle was investigated, it was noticed that the histologic aspect of tissues of Group 1 was usual.

Our results revealed that the biochemical TAC and OSI levels in both the torsioned and detorsioned testis were statistically significant, where the biochemical TOS level in both the torsioned and detorsioned testis were not statistically significant. We noticed significantly decreased OSI and improved TAC with the application of Piracetam, which could partially be depended to the agent's antioxidative and free-radical scavenging preoperties. On the other hand our histopathologic results did not show the changes on the tissue level. This may be associated with the application dose or tissue relation of the drug or the method. Various models may be used in order to determine the effects on histopathological level.

According to our findings, the different application form and duration of piracetam may cause histopathological improvement and further studies are necessary in order to show the apparent effects. Further studies should investigate different administration methods, different doses and different duration of Piracetam.
In conclusion, piracetam therapy increased antioxidant activity and decreased oxidative stress scores in testicular samples. However, it did not cause alteration in histopathological examination and spermatogenesis scores.

\section{REFERENCES}

1. Williamson RC. The continuing conundrum of testicular torsion. Br J Surg. 1985; 72: 509-10.

2. Beheshtian A, Salmasi AH, Payabvash S, et al. Protective effects of sildenafil administration on testicular torsion/detorsion damage in rats. World $\mathrm{J}$ Urol. 2008; 26: 197-202.

3. Gukasov VM, Rasulov MM, Efuni SN, Kaplan EIa, Smiriagina VI. Characteristics of the antihypoxic action of piracetam. Biull Eksp Biol Med. 1987; 103: 683-5.

4. Tortiglione A, Minale M, Pignataro G, Amoroso S, DiRenzo G, Annunziato L. The 2oxopyrrolidinacetamide piracetam reduces infarct brain volume induced by permanent middle cerebral artery occlusion in male rats. Neuropharmacology. 2002; 43: 427-33.

5. Rauca C, Jantze H, Krug M. Does fucose or piracetam modify the effect of hypoxia preconditioning against pentylenetetrazol-induced seizures? Brain Res. 2000; 13; 187-90.

6. Hanon E, Klitgaard H. Neuroprotective properties of the novel antiepileptic drug levetiracetam in the rat middle cerebral artery occlusion model of focal cerebral ischemia. Seizure. 2001; 10(4): 287-93.

7. Ricci S, Celani MG, Cantisani TA, Righetti E. Piracetam in acute stroke: a systematic review. J Neurol. 2000; 247(4): 263-6.

8. Johnsen SG. Testicular biopsy score count-a method for registration of spermatogenesis in human testes: normal values and results of 335 hypogonadal males. Hormones. 1970; 1: 2-25. 
9. Erel O. A novel automated method to measure total antioxidant response against potent free radical reactions. Clin Biochem. 2004; 37: 112-9.

10. Erel O. A new automated colorimetric method for measuring total oxidant status. Clin Biochem. 2005; 38: 1103-11.

11. Lysiak JJ, Zheng S, Woodson R, Turner TT. Caspase 9 dependent pathway to murine germ cell apoptosis: Mediation by oxidative stress, BAX, and caspase 2. Cell Tissue Res. 2007; 328: 411-49.

12. Guimaraes SB, Aragao AA, Santos JM, Kimura Ode S, Barbosa PH, Vasconcelos PR. Oxidative stress induced by torsion of the spermatic cord in young rats. Acta Cir Bras. 2007; 22: 30-3.

13. Avlan D, Erdogan K, Cimen B, Dusmez Apa D, Cinel I, Aksoyek S. The protective effect of selenium on ipsilateral and contralateral testes in testicular reperfusion injury. Pediatr Surg Int. 2005; 21: $274-8$

14. Uguralp S, Usta U, Mizrak B. Resveratrol may reduce apoptosis of rat testicular germ cells after experimental testicular torsion. Eur J Pediatr Surg. 2005; 15: 333-6.

15. Dokmeci D, Inan M, Basaran UN, et al. Protective effect of L-carnitine on testicular ischaemia/reperfusion injury in rats. Cell Biochem Funct. 2007; 25: 611-8.

16. Unal S, Ozmen S, Demir Y, et al. The effect of gradually increased blood flow on ischemiareperfusion injury. Ann Plast Surg. 2001; 47(4): 412-6.

17. Horvath B, Marton Z, Halmosi R, et al. In vitro antioxidant properties of pentoxifylline, piracetam, and vinpocetine. Clin Neuropharmacol. 2002; 25(1): 37-42.

18. Bick RL. In-vivo platelet inhibition by piracetam. Lancet. 1979; 2(8145): 752-3.
19. Rossillon D, Vanwyck R, Bayet B, Calteux N, De Coninck A. The action of piracetam in ischaemic flaps. Br J Plast Surg. 1987; 40(5): 459-66.

20. Tuncer S, Ayhan S, Findikcioglu K, Ergun H, Tuncer I. Effect of systemic piracetam treatment on flap survival and vascular endothelial growth factor expression after ischemia-reperfusion injury. J Reconstr Microsurg. 2011; 27: 409-18.

21. Nalbandian RM, Henry RL, Burek CL, et al. Diminished adherence of sickle erythrocytes to cultured vascular endothelium by piracetam. Am J Hematol. 1983, 15(2): 147-51.

22. Trevisan M, Browne R, Ram M, et al. Correlates of markers of oxidative status in the general population. Am J Epidemiol. 2001; 154(4): 348-56.

23. Zhu YJ, Zeng T, Zhu YB, et al. Effects of acrylamide on the nervous tissue antioxidant system and sciatic nerve electrophysiology in the rat. Neurochem Res. 2008; 33(11): 2310-7. 